\title{
APBA3 wt Allele
}

National Cancer Institute

\section{Source}

National Cancer Institute. APBA3 wt Allele. NCI Thesaurus. Code C104849.

Human APBA3 wild-type allele is located in the vicinity of 19p13.3 and is approximately 11 $\mathrm{kb}$ in length. This allele, which encodes amyloid beta A4 precursor protein-binding family A member 3 protein, plays a role in amyloid beta A4 precursor protein binding. 